\section{9 中南春修水利工程結束}

中南區湖南省修復堤垸三百四十七個，挖塘八萬五 千口, 修渠一百二十避。湖北修開增一百七十二個, 挖 塘七千九百口。江西它完成㗆安渠、安福渠、其他塘溯 中小型水利工程三千三百八十六座。全區受盆面積三百 萬畧。

（長江日啹）

\section{0 引黄濟衛工程測量完畢}

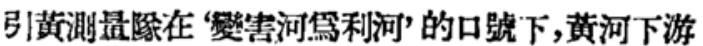
歷史上, 第一次利用黄水浩福人民的引㣴水濟衛河.工程 已测量完里，將于·今年沉期後閉始施.T。

$$
\text { （人民日報） }
$$

\section{國外之 部}

\section{1 全蘇科學院會議閉幕}

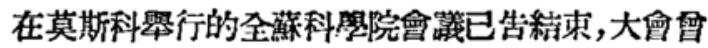

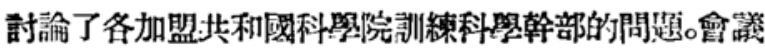

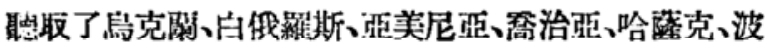
羅的海沿岸各共和國及其他备加盟共和國代表的報告。 通些代表在報告中生预地描 述了各科學部; 練青年專家的情况。現在, 在各共和國科學院所組織的

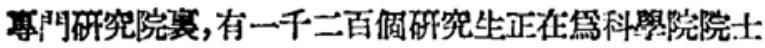
读選人的㾞格和科然场士學位而寫作論文; 有二千三百

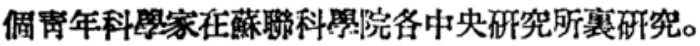

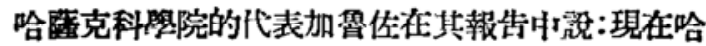

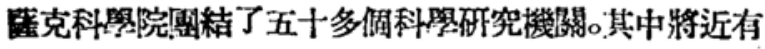
一千五百人正在從事科照研究，常中有二百六十五名是 哈隆克婦女, 今年已有許多研究生濩得了學位。牲畜帥司

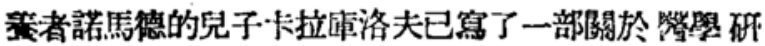
究的有價值的著作; 他已在病理學研究所寒任:職。另一

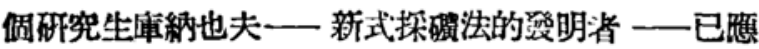
邀在地盆罢研究所裹.工作。今年將有一百二十五個研究 生在哈落克科祭院研究。

(新華行稿)

\section{2 举四原子科學家將赴倫敦參加 世界動力會議}

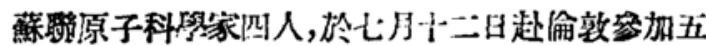
十國世界動力會䣡, 討論原子能的和平用途問題。英國 原子物理學家檴威科克維夫博士於七月十四日在大會 中發表原子能和平用途問題的濥設。

（南僑日報）

\section{3 蘇科學家代表團赴柏林落加德 科學院慶典}

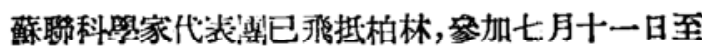
十六日舉行的德意志科照院二百五十造年紀念曼典。代 表圈由下列諸人組成：科路院院士維典斯基 (代表團團 長)、烏克閶枓照院院長巴拉丁、科學院院士杜比察、丝

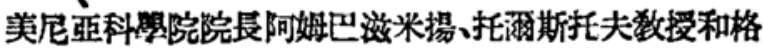
拉的列夫数授。

(新華社稿)

\section{4 李森科院士向農民介紹粒狀肥} 料方法

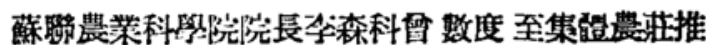
獚粒狀肥料的施用方法。此锤肥料可人大的提高牧草的
收缹最。

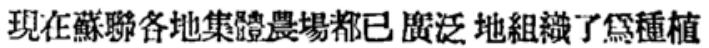
多年牧草和的司料作物的粒狀肥料的製造。

（筫話報）

\section{5 英科學家貝爾納盛㲋蘚聯科學 成就}

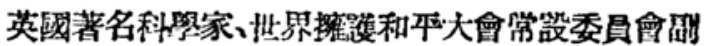
主席貝爾納，近曾在堬敦發表了一篇题第 '馬克思與科 䋰, 的演說。對於蕉聯科學成就,盛讚不已。

(䡚話報)

\section{6 蘇聯成立新式鄉村建築研究所}

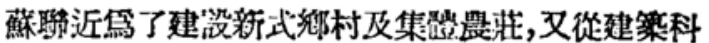
學研究所襄另外分出了一個新式鄉村建築研究所, 專門 設壾和研究㝜村的建築。

(望話報)

\section{7 蘇科學家蘇卡契夫榮腐列寧郢章}

蘚聯科學院院.土森林罗 聯生物學界最宗越的代表之一，因䉆他在植物生理祭、

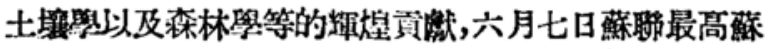

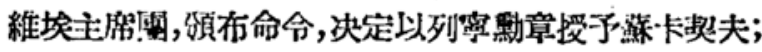

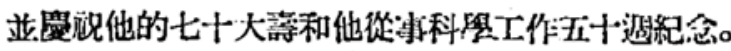

(新茜社滳)

\section{8 李森科又榮俩美契尼科夫金質 獎章}

葆聯科祭院主席滇已將一九五 ○年美契尼科夫金

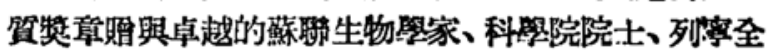
蘇農栄科照院院長䒚森科。（新華社稿）

\section{9 蘇聯以人工凝土法開掘新碾井}

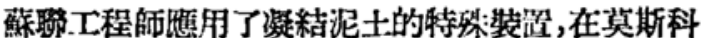
坑道。從前風監一個五十公尺深的刹坑井需要二十天， 而現在瑾一天牛就够了。

（算話報）

\section{0 穌聯獎洞科學工作者及制定金 獎章二種}

蘚聯政府近又制定了 米邱林 金獎音和威麻士金獎

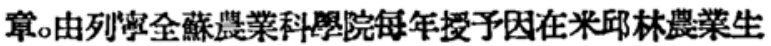

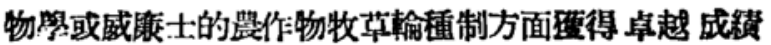
的科學工作者。

（實話報）

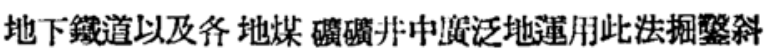




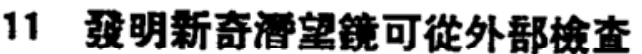 水管子}

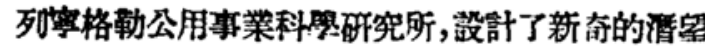
鏡，用此䔔在城市水道管的外面就可查知水道智內部的

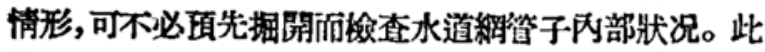

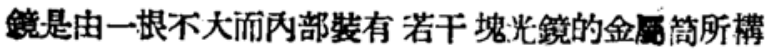

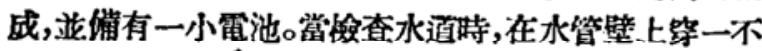

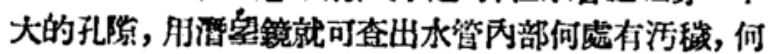
啮有沙子堵害或生銹現象。

（惯話啹）

\section{2 蘇聯工程師弡明捕魚新法}

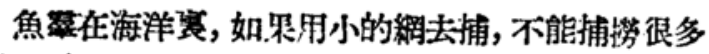

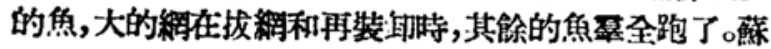

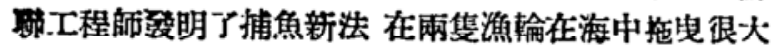

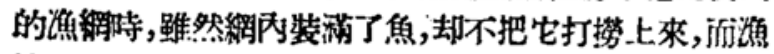
輪不停地行駛着, 只有一隻跟着一隻的空漁船来到漁 稐，用抽魚哪筒的方法，在漁䋨的中央部分裝一個網呪， 從外面堵住非金殿管子, 管子的另一端和漁輪的抽魚唧

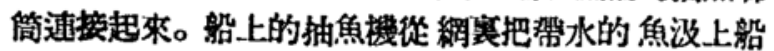
來, 魚倒進沿䑪裹, 水流下海赛, 一隻一隻的裝溇了魚後

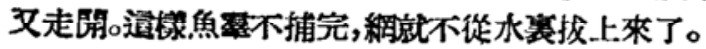

\section{(䖝話趣)}

\section{3 海上馬路} 來。

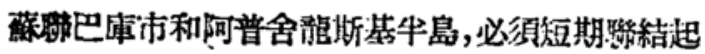

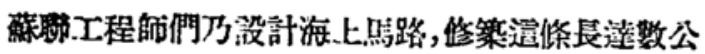

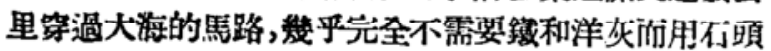
和砂子焦成的。他們先用石頭投入海中, 成鹄兩條平行 的石堆,作鹪新践路的侧基; 然後用水力冲㢣眇子, 由抽

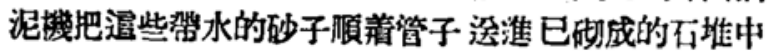

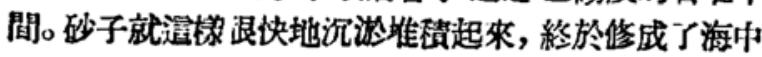
的長堤大馬路了。

（實話報）

\section{4 群聠新設了幾個畜牧業研究機關}

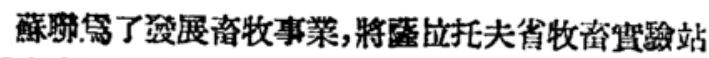

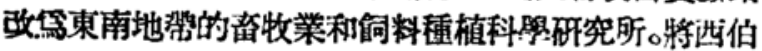

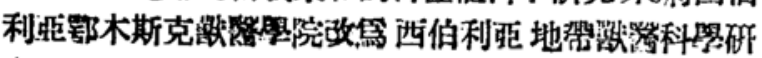
究所; 及在海闌泡成立遠東地势鄂整科祭研究所。

（苴話報）

\section{5 蘇聠科學院䅉史學㙛士完成 “朝鲜人’亭著}

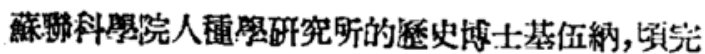
成了他的專著“朝鲜人的論文。作者踓用他住三十五年 前旅行朝解時阶㮴集的材料, 有名的十八世紀的朝解酒 科全畫和最沂交祭方面的材料, 完成了他的著述。諭文 概䢞了朝鲜人的迟源, 及其人種組成，朝鮮的社會制度與

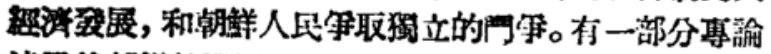
述臹後朝鮮的玐展。

\section{（新華社稿）}

\section{6 蘇聯新媓'朝鮮'出版}

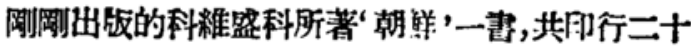

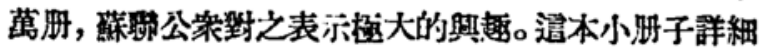
叙边了朝解民主主㼁人民共和闌的症史、國家和行政制

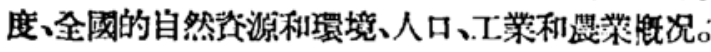

該書是由鮛聯科然院通訊院士装夫吉尼. 朱可夫立 絀印行的。

(新菲泣稿)

\section{7 蘇聯的新式柴油機車}

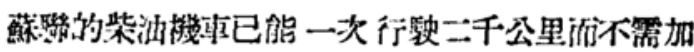

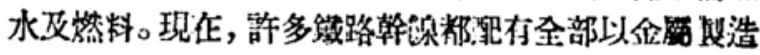

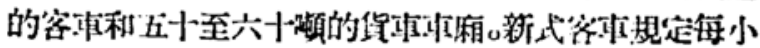

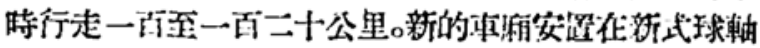

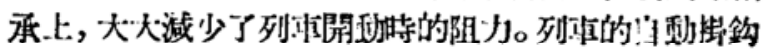

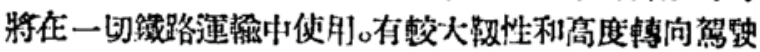

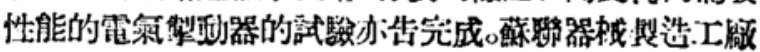

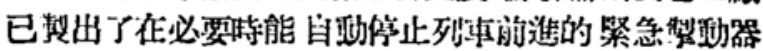
的僈良模型。

(新䒜社稿)

\section{8 蘇聯科學院建築磁究所近况}

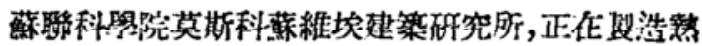

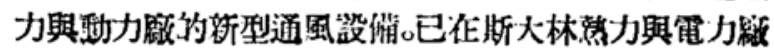

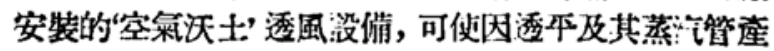

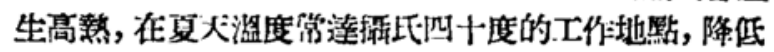
温度到䕐氐二十五度。

(䂯萿㫌稿)

\section{9 蘇㖒的植物生長刺激素}

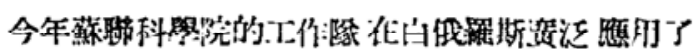

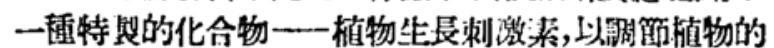

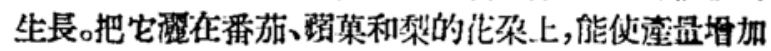

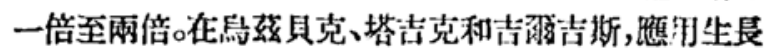

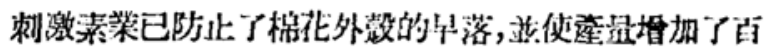

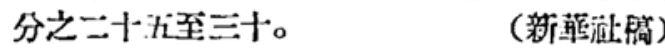

\section{0 新式的陉甜荣聯合譏}

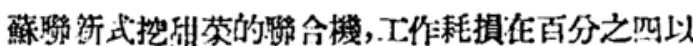
下, 而美國熙別特公司的機器的工作耗損第页分之二十

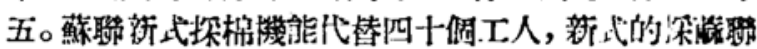

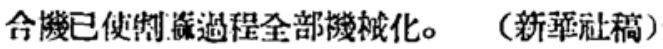

\section{1 蘇聯科學家移植高等動物器官 已完全成功}

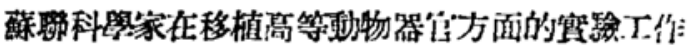

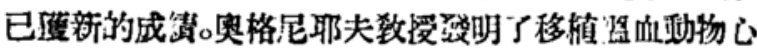

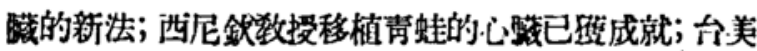

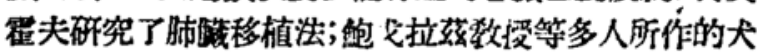

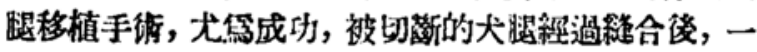

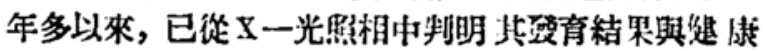
犬無照。

$$
\text { (新嚄社稿) }
$$

\section{2 蘇科學家費拉托夫受惩}

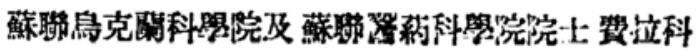




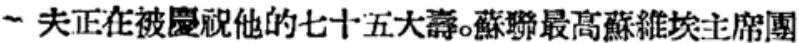

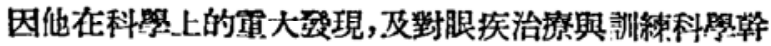

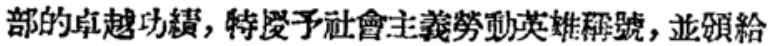

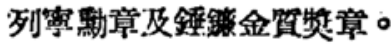
（新茾顽稿）

\section{3 独聯弡明了試驗人類埴學力 新法}

鮛聯巴甫洛夫生理學研究所人员已成功地解决了

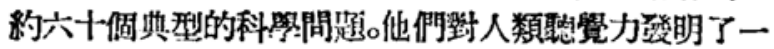

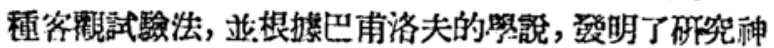
經錯亂考的一貫情緒的方法。他們創浩了一種測氡計，

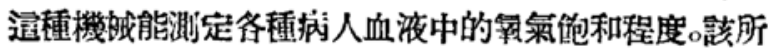

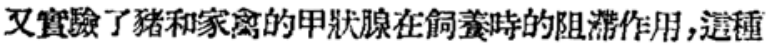

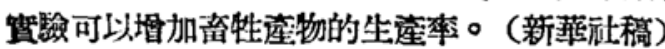

\section{4 羅馬尼亞科學界舉行紀念澾西薾 文座談會}

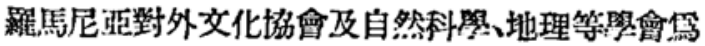

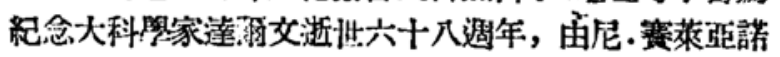

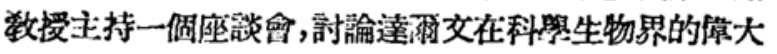
貢戲。

（新羅馬尼味報）

\section{5 德國洪保德大學氣象系近况}

德意志民主共和國 柏林洪保德 大留或像系現由厄

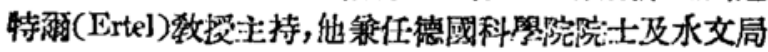

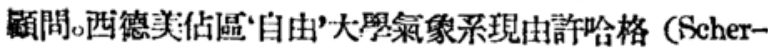
hag)情士主持。

\section{6 平壤附近開湾運河大同江並增 建江橋}

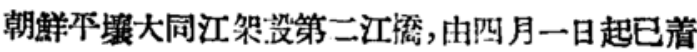
手籍借.工作。該工工程颛定由一九五一年起開.工, 至一九 五三年竣. 里汇宸, 比現在的大同橋加窅二倍牛。

平爙渾河.工事, 從阿月一日起佂平壤市民的勞力援

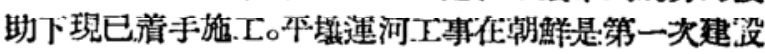

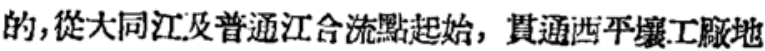

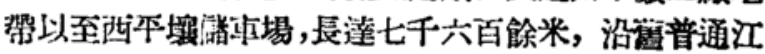

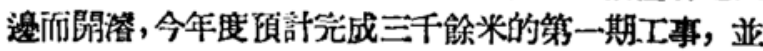
將役置調節水位的渴阴一處。倘第一期.工事完竣, 六十

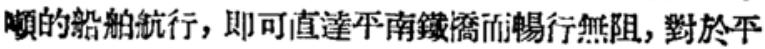

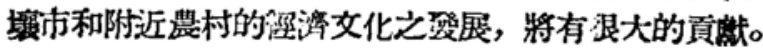

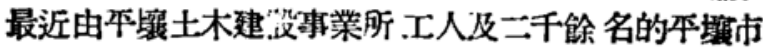
民青手掘底和堤防.工事, 正在活躍的淮行中，他們决心 在八、一五以前,䒕成今年度計燔。

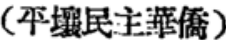

\section{7 羅科學工作者向英美科學家 呼籍和本}

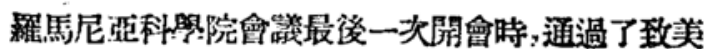

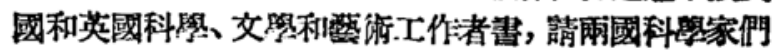
鳥和平服務。

(新華斻稿)

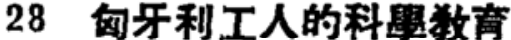

侧牙利第了詶紼冶金工業.工人，在國內建立了很多

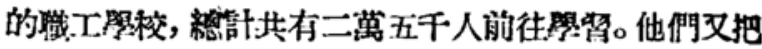

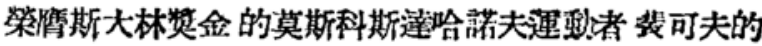

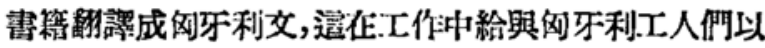
很電恐的幫助，

（蕕聯青年技衡）

\section{9 羅馬尼亞開鏊運河近訊}

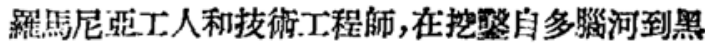

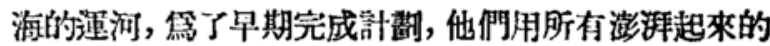

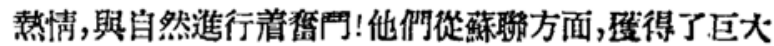

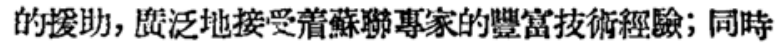
從蘇聯淦到了田地棑作用的最新式的機器, “斯大林號

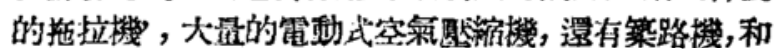
本發電機和其他式埊的没偳。

兄弟的人民民主共和國也 給了運河開繁者 以很大

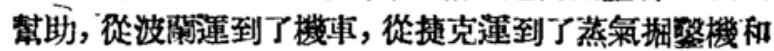
柴油引擎掘鳘機。

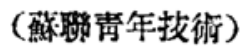

\section{0 匈牙利將藇行國際數學會境}

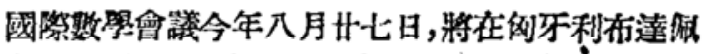

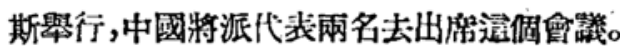

(掘)

\section{1 波蘭譽行第二屆天文學家大合}

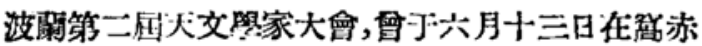
亞威克舉行, 蕉聯天文學家数人應邀出席此次大會。 (新蕉流稿)

\section{2 在羅馬尼亞有色金屬冶金事業 的發展}

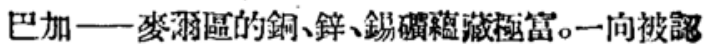

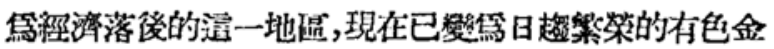

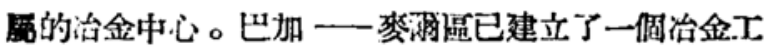

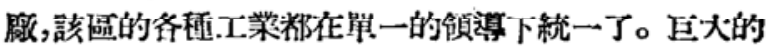
勘碵工程正淮行中。

\section{（雪取持久和平，释取人民民主）}

\section{3 波蘭斯達哈諾夫工作者合議}

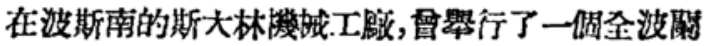
會锇,討論用该速的方法制河五金。出席塄储會議的,有 七百五十個長於這種工作方法的斯迲哈諾夫.工作者、生

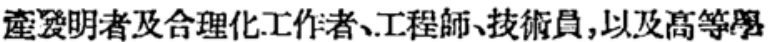
校的教授。

五金加.工的快速方法，是由麥特洞同志首领的，他 是波斯的斯大林機峨.工做的事休.工人。現在全國機器慗

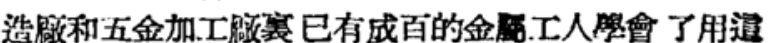
種方法。到處都在學珀藮聯斯達哈諾夫工作者的工作方 法。

（雪取持久和本，雪取人民民主）

\section{4 英國策象學會舉行百週年紀念}

英國皇家氣象整會在本年三月卟八日 至四月三日 


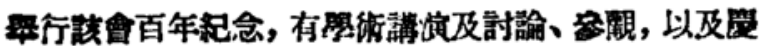

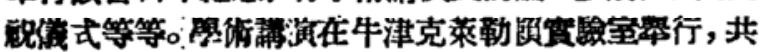

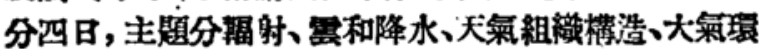

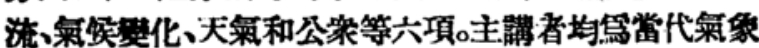

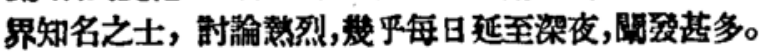
到會者有一、二百人,國外來宾幾佔一牛。（潮）

\section{5 天空間預告的試験}

美國音林斯頓近代科照研究所数授錢耐(Charneg) 氏主持数値预告研究,現在已開始在本雪凡尼亞大敗電 子計算機上作二度空間颛告的試緊。

(潮)

\section{6 垹威奧斯陸大學討論天體物理 學}

挪威奥斯陸大學天體物理學研究所,佂四月沟請了

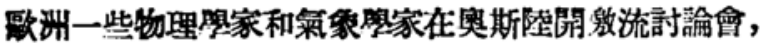

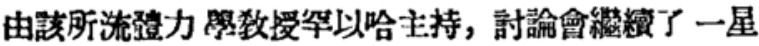
期。

\section{7 芬蔽設立北桎高空氣象台}

芬闌氣象局在北極圈內沙打干來 (Sodankylä)地方

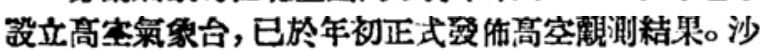
打干來地磁合洂已復㷋.工作。

(湖)

\section{8 居里数授重返學府法國學生熱} 烈歡迎

被法國皮杜雨反動政府乘承美帝意旨解除了原子 能高級專員和原子能委員會委員暴務的約里感・居里教

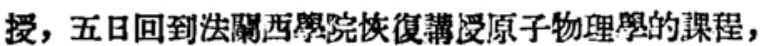
受到學生們河熱烈的䧶迎。

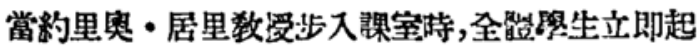
立政敬，並高唱'孯赛淮行曲'(法國國歌)。

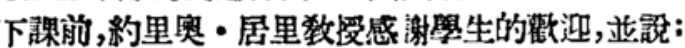

“你們踊躍來上課,表示了必須把科學的淮步專門的於 促淮世界和平及人類的幸福。”

\section{（港大公嘏）}

\section{9 風滀㾝底新藥}

美國有一臣名叫“化合物 $\mathrm{E}$ ”的新获可以治潦風缹原

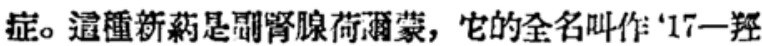

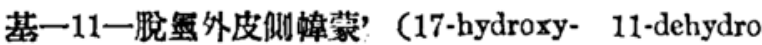
Corticosterone)。它底綜合银浩,包含三十個以上的中問

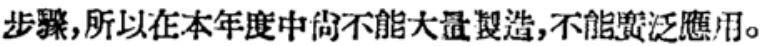
（美國科學通訊遇刊）

\section{0 一種能找害癌腫的新化合物}

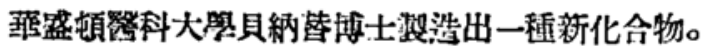
通種化合物含有永原子,當它與含有硫䛼基 Sulfhydry] group 的化合物接獨時便生成紅色化合物; 因此它能够

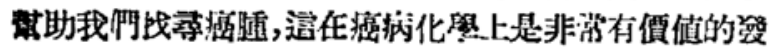
現。 （美國科照通訊䓢刊）

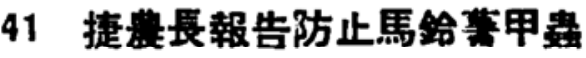 措施}

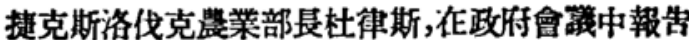

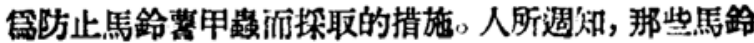

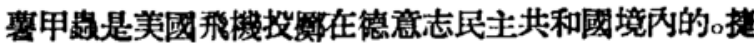

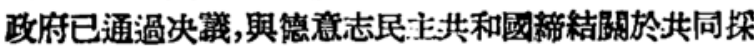

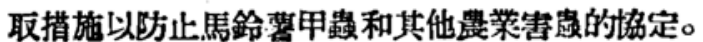
(新菲社稿)

\section{-42 非洲蘇丹蕾石器時代的研究}

最近出版的阿克爾 (A.J. Arkell) 氏的萑丹古蹟

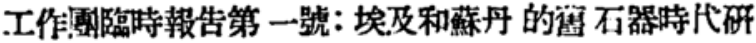
究 (劍谓Deigton, Bell and Co Ltd.,1949) 一書, 對

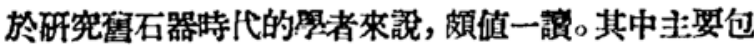

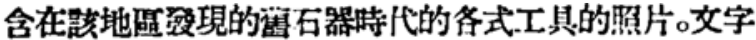

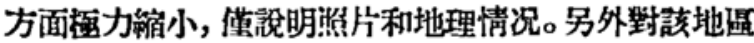

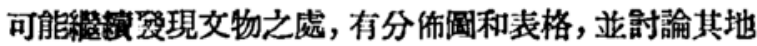

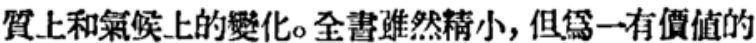
科祭著作。

（英國·自然 4184期19頁）

\section{3 印度心䁍雜誌}

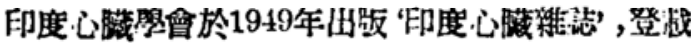
有關心瞒的，血液循環的和其他有關的論交。創刊躆內 容包括六篇原著(作者都是印度人),和一些時代名著的

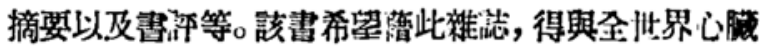
䍙者有所聯䠌。

（'自然 4191期303頁）

\section{4 比利時“新科學雜誌出版}

比利時的月刊新科學(Sciences Modernes)㓣印唬已

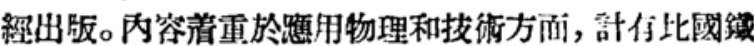

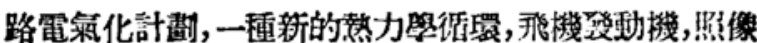

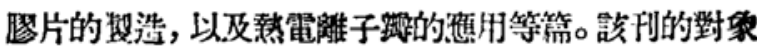

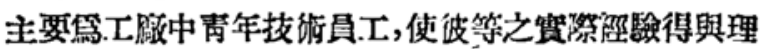
論結合。

( '自然' 4195期470頁)

\section{5 各國宇宙線研究譏構一責表}

\section{出版}

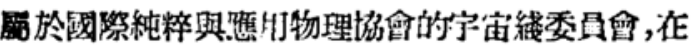
1947年格拉哥 (Cracow) 會議中曾决定草緛對於宇寉路 研究機槽一切有關资料的一㹂表。其中特別包含殿迎外 籍.工作人员加.工作的研究機柫。該表踓储未傣完美，

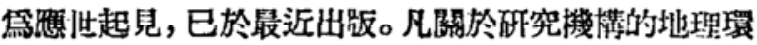

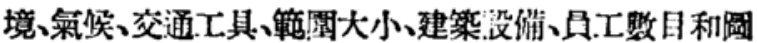

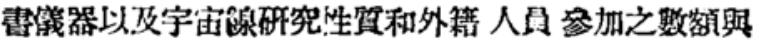
標”傕等問題，無不在表中有詳盡之解答。材料之收集來

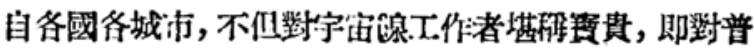

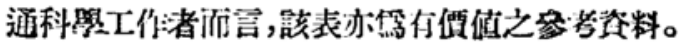

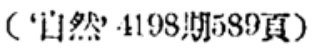

46 瑞士植物雜誌“Maveg”郎將 問世

瑞:士存一新季刊“Maveg”將於经期汹仙版。硋打 


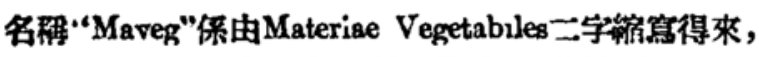

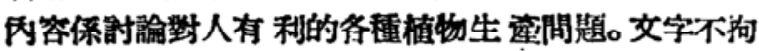
國別,但均有英交摘姴。

\section{( “自然 4191期512頁)}

47 舁大利科學雜誌 “L'illustrazions Scientific"出版

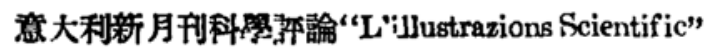

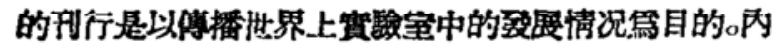

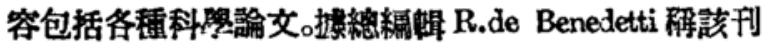

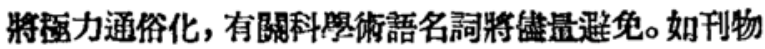
名稳所示,該刊韩以多数然片和讉明。

\section{(“自然 4197期552頁)}

\section{8 超㢣波對晶體的效應}

在意大利科暗記錄( La Ricerca Scientifica)(羅馬, 1949年8月)上,李維(Franco A. Levi) 發表一篇超鹳波

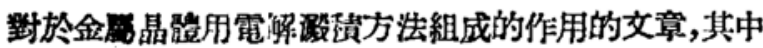
叙边了所用的㼁器和所得的結.果o超緊波是由於筑電晶

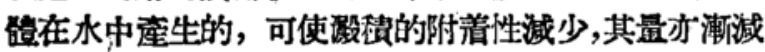

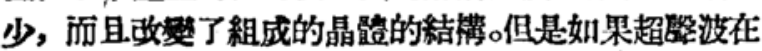
晶酷租成以後方始作用時, 則通種改能未能得到。結論

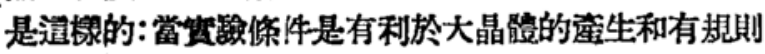

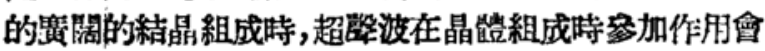

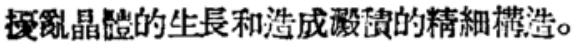

\section{(“自然·1190期264頁)}

\section{9 英國墢行蘇聯科學期刊的英 譯一覽表}

英國科盟與工業研究部按期發行了存關莉聯的科

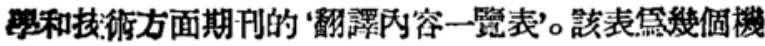

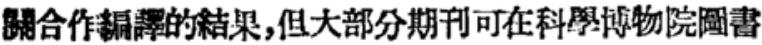

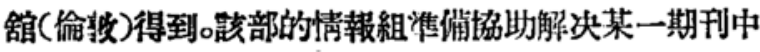
特別部分有所不了解的地方, 同時茞明對願意影譯而本 身不能得到期刊的機構可能出借一筧表中所登的期刊。 最近一期一筧表(第四期19.9年9月)包含了二十三種期

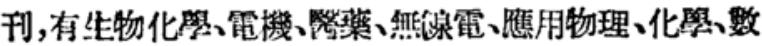

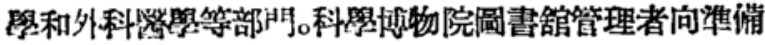

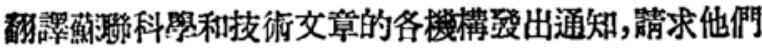

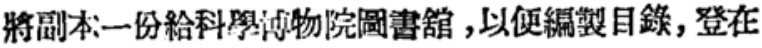
圖甾舒的坦到表中。（“自然' 4190期264頁）

\section{0 德國化學中心年鑑}

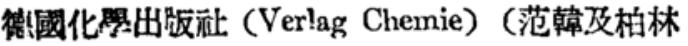
Weinheim and Berlin) 宣䊈化祭中心年鑑 (Chemisches Zentralblatt) 将於1950年1月出版,書分二参, 在傳統形 式下一次發行。包括了所有化罢著述。多年以來該年䠄

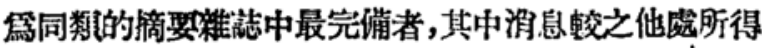

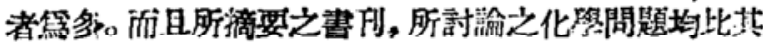

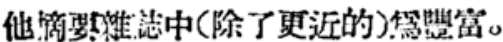

( '自然 4190 期 26.1 項)

\section{1 自動䅝制鈛棫}

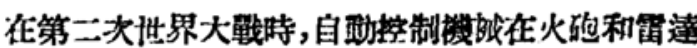
方面的没計和應用已有非凡的進展,現在由於新.工業的

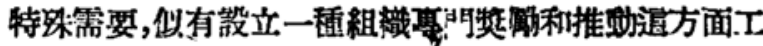
作的必要。各工程顋會有時也討論到其中某些間䟎 但

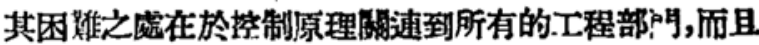

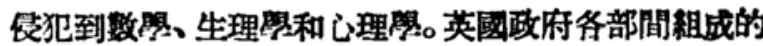

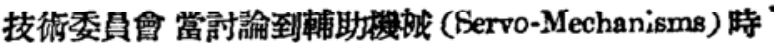

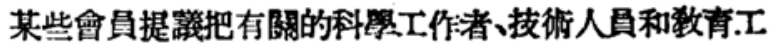

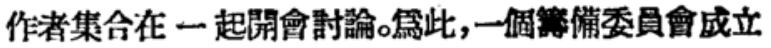
了, 同時向媵器工程學會(Society of Jnstrument Techn-

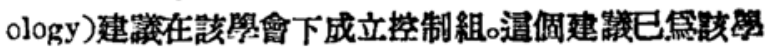

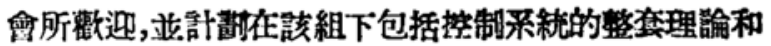

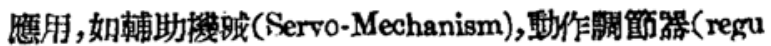

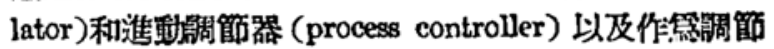
器之用的, 或爲某大控制系統中一部分的人的功作間題 等,都包含在內。大會開意式,將於三月二十八日在倫敦 舉行,會中宣䉝三篇短小論文:海葉斯( K. A. Hayes)

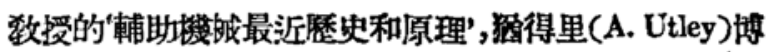
士的 “安定裝置問題”, 及杜斯汀(A.Tustin)㥢授的 “有待 解决的控制染統中的問题。所有對空制譏放及有關間

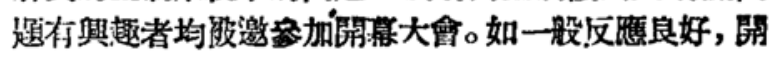

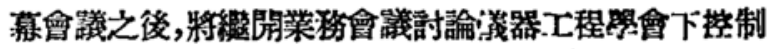
組的成立問題。 ( '自然 4190期264頁)

\section{2 射頻光譜學的國際會䛨}

討論射頻光諧學的國際會議將於 9 月 18 - 23 日在

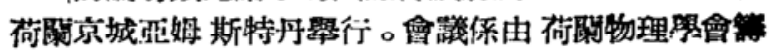

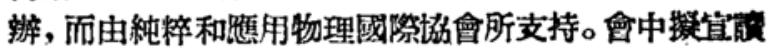

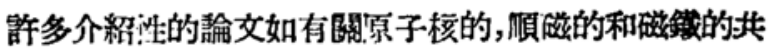
振, 及用射頻(radio frequency)方法對原子和分子常数 的精密测定等。此等稐文將繼以討諭。此外問题將在小

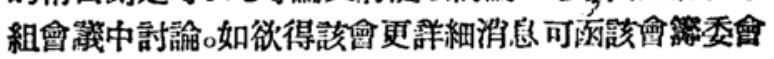
秘書波爾数授 (Prof.J. de Boer, Bunsenstreat $\mathrm{C8}$, Am$s_{\text {terdam }-0 .)}$

('目然' 4190期”65頁)

\section{3 南非的石突葲術}

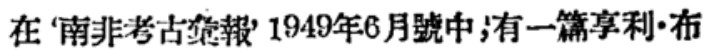

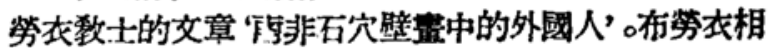

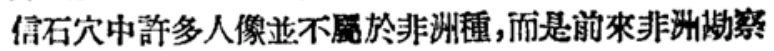

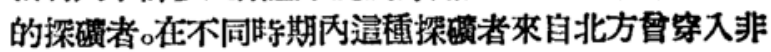

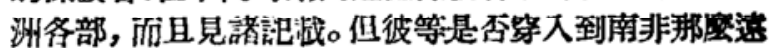

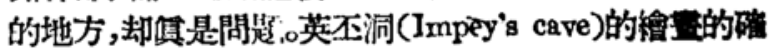
命人追想到在北非拧穴中存外人的管現。但對班圖(Ban tu南非中非的土人)䁷䘕和它的酸展的充分的研究有没 有過呢? 在趛方面徝得提到的是貝德愿(Canon Fdward Paterson of Cyrene, Southern Rhodesia) 對班岡罗童的

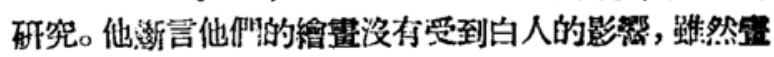

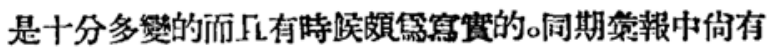
古德文 (A. J. H. Goodwin) 所寫的一則短訊, 報道東 格列瓜闌(East (iriqualand) (满南非開普州)的漁景繪 


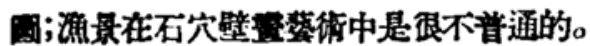

（'自然 4189期222頁）

\section{4 嚄石器時代研究令䛨}

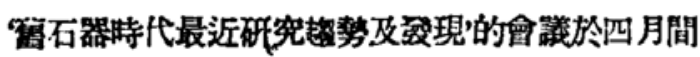

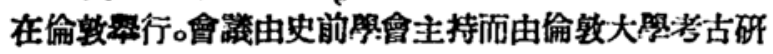

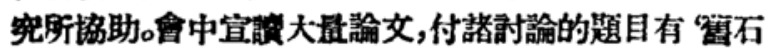

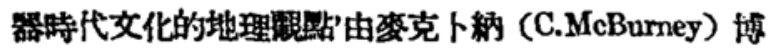
士、卜克特(M. C. Burkitt)先生、凯萊(H. Kelley)先生、 奥克萊(K. Oakly)博士、和拉開(A. D. Lacaille) 先生 加, 及呵洲上瓷石器代的起源'由拉開先生作介

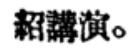

(“自然1189期22頂)

\section{5 分析化學的國際會議}

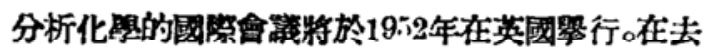

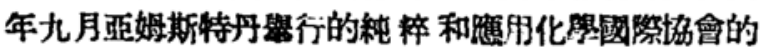

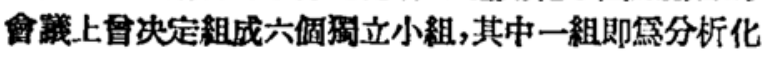

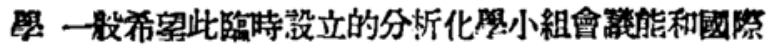

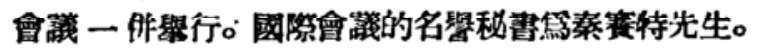
(Mr.R. C. Chirnside, Research Laboratories of the General Electric Co. Ltd., Wembley, Middlesex)

('自然4189期223頁)

\section{6 第六屆科學史國際合議}

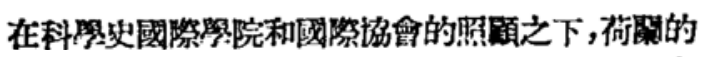
國際協會分會正在篅辦將於八月十四日至二十一日在

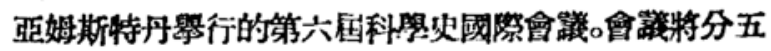

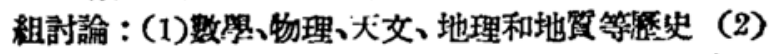

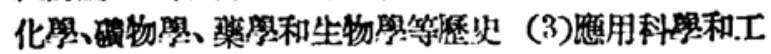

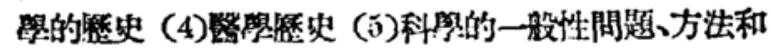

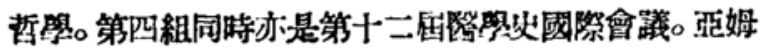

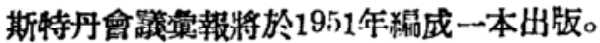

('自然4198期592頁)

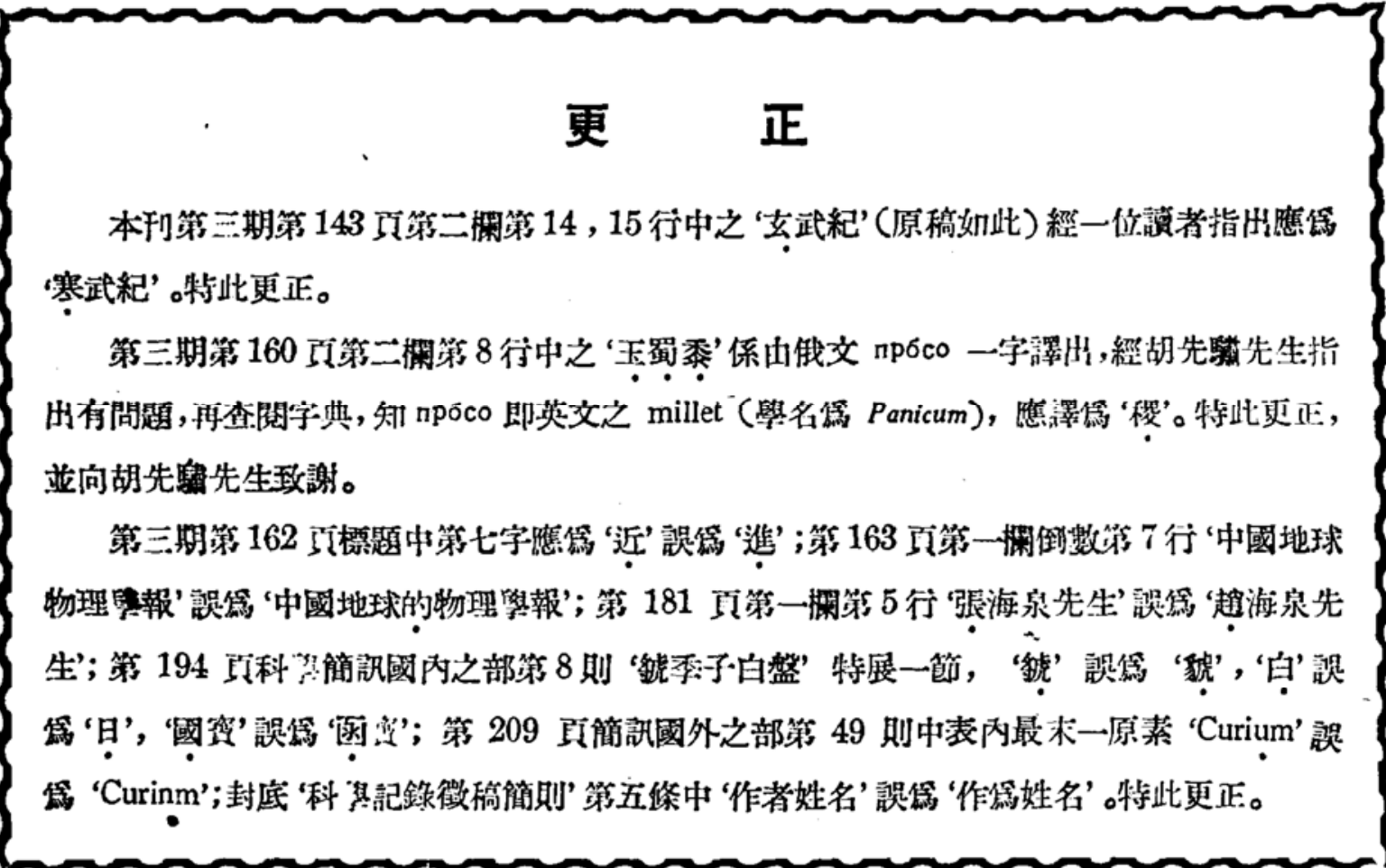

